\title{
Potential of Water Vending Machine to Remove Trihalomethanes and Heavy Metals During High and Low Water Seasons in Petropavlovsk
}

\author{
Audrius Dėdelè ${ }^{1}$, Nazim I. Nikiforov ${ }^{1 *}$, Aida N. Madieva ${ }^{2}$, Auksė Miškinytė ${ }^{1}$ \\ ${ }^{1}$ Department of Environmental Sciences, Faculty of Natural Sciences, Vytautas Magnus University, \\ Universiteto Street 10, 53361 Akademija, Lithuania \\ ${ }^{2}$ Department of Physiology, Faculty of Biology and Geography, Buketov University, 100028, Karaganda, Kazakhstan
}

Received: 19 July 2021

Accepted: 21 October 2021

\begin{abstract}
The potential of water vending machine to remove chloroform $\left(\mathrm{CHCl}_{3}\right)$, bromoform $\left(\mathrm{CHBr}_{3}\right)$, bromodichloromethane $\left(\mathrm{CHBrCl}_{2}\right)$, lead $\left(\mathrm{Pb}^{2+}\right)$, and chromium $\left(\mathrm{Cr}^{6+}\right)$ during high and low water seasons was investigated in Petropavlovsk, Kazakhstan. The water samples were collected from the water supply network during the high and low water seasons and were analyzed for $\mathrm{CHCl}_{3}, \mathrm{CHBr}_{3}, \mathrm{CHBrCl}_{2}$, $\mathrm{Pb}^{2+}$, and $\mathrm{Cr}^{6+}$. The retention coefficients of $\mathrm{CHCl}_{3}$ by the water vending machine were $54.3 \%$ and $67.4 \%$ during the high and low water seasons, respectively. $\mathrm{Pb}^{2+}$ concentrations decreased by $88.9 \%$ and $84.5 \%$ during the high and low water seasons, respectively. The concentrations of $\mathrm{CHCl}_{2} \mathrm{Br}$ were increased by $26.7 \%$ during the high water season, while during the low water season, this pollutant was removed completely. $\mathrm{CHBr}_{3}$ was completely removed during both seasons, while $\mathrm{Cr}^{6+}$ was removed during the low water season. Statistically significant differences were found in the concentrations of chloroform and lead between the classically and advanced purified water during the high and low water seasons $(p<0.05)$. Meanwhile, statistically significant differences in the concentrations of bromoform between the classically and advanced purified water were only found during the low water season $(p<0.05)$.
\end{abstract}

Keywords: drinking water, trihalomethanes, heavy metals, water vending machine

\section{Introduction}

Water vending machine is any self-service device that upon insertion of money or tokens or upon receipt

*e-mail: nazim.nikiforov@vdu.lt of payment by other means, dispenses unit servings of water in bulk into a container, without the necessity of refilling the machine between each operation $[1,2]$. Water vending machines are installed in order to improve the quality of drinking water in terms of organic, inorganic and bacteria content $[2,3]$. There has been an exponential increase in the public availability of WVMs in urban areas, driven by modern working 
and public infrastructures, lifestyle changes, and water drinking habits. Sales of WVMs are also influenced by local conditions such as ease of access to clean drinking water, convenience of the location, humanfriendly services, low setup cost, and labor [4, 5]. WVMs vary in technical characteristics, the number of stages of water purification, and it can also be centralized, taking water from a central water supply system [6, 7], or decentralized, for example, taking water from groundwater [7]. The most primitive water vending machines are those that include only one stage of treatment - mechanical filtration. Such installations are aimed at improving the basic parameters of water such as taste, odor and turbidity [6]. Other machines may include a larger number of purification stages, among which different-pore-size mechanical filters, activated carbon filters, reverse osmosis filters, calcitemineralization, ultraviolet disinfection, ozonation and other stages [7-10]. Depending on particular pollutants in raw water, certain stages of purification are employed. For example, activated carbon and reverse osmosis filters are effective in reducing the concentrations of organic compounds and heavy metals [11, 12] while ultraviolet disinfection and ozonation promote the prevention of bacteriological contamination [13-15].

Water vending machines have recently been an object for many water quality investigations. There are some studies that revealed that the use of WVM can negatively affect the microbial quality of water $[16,17]$. On another hand, there are findings that stated about complying of the vended water quality with national and international regulations in the most of physical, chemical and biological parameters (such as $\mathrm{pH}$, total dissolved solutions, turbidity, total organic carbon, coliforms, heavy metals) [18, 19]. Only an exception was in the El-Naggar's studies which showed that the vended water can content chromium concentrations higher than those in the WHO and US EPA guidelines [19].

However, there is a window for research about to what extent certain unregulated and regulated pollutants of drinking water, such as trihalomethanes (THMs) and heavy metals (HMs), are removed by the water vending machine in the high and low water seasons. To our knowledge, no studies have been conducted for examining the seasonal removal potential of the water vending machine in terms of chloroform $\left(\mathrm{CHCl}_{3}\right)$, bromoform $\left(\mathrm{CHBr}_{3}\right)$, bromodichloromethane $\left(\mathrm{CHBrCl}_{2}\right)$, lead $\left(\mathrm{Pb}^{2+}\right)$, and chromium $\left(\mathrm{Cr}^{6+}\right)$.

The trihalomethanes are formed in water chlorination processes by reacting of free chlorine with naturally occurring organic matters such as fulvic and humic acids [20-22]. The level of chromium observed in the corrosion scales has exceeded the level observed in earth crust [23]. Under oxidative conditions in drinking water, as well as in scenarios involving rapid changes in source water and related water chemistry, the deposited chromium can be released back into drinking water, resulting in an elevated concentration of $\mathrm{Cr}^{6+}$ level at the tap [24], in turn, lead appeared from corrosive water effects on household plumbing systems containing lead in pipes [25]. All those preconditions occurred in the study area: drinking water supply enterprise (DWSE) uses chlorine $\left(\mathrm{Cl}^{-}\right)$as a disinfectant; and the majority of the water distribution network consists of outage corrosive metal pipelines, 70\% the water distribution network is worn out [26].

Over the last decade, Petropavlovsk entrepreneurs have ubiquitously installed the WVM in the city in order to improve the quality of water supplied from the DWSE in term of physicochemical and bacteriological pollutions since it has recently decreased [27]. The devices are installed by within walking distance at residential buildings, pharmacies, stores and other public buildings, residents come with their containers and buy water from the devices. Thus, the population has access to the two commercial types of drinking water (classically and advanced purified). The latter option is a more expensive one. However, the consumers may incur additional costs and have the same or even higher exposure to pollutants from the advanced treated water as the findings of studies showed in Malaysia, for example [16]. THMs are of concern due to possible cancer risks and other sub-chronic/chronic health effects on humans [28, 29, 30]. $\mathrm{Pb}^{2+}$ is a cumulative general poison with infants, children up to 6 years of age, fetuses and pregnant women being the most susceptible to adverse health effects [31]. There is evidence that exposure to chromium in its $\mathrm{Cr}^{6+}$ oxidation state is associated with lung cancer, nasal irritation, nasal ulcers, hypersensitivity reactions, and contact dermatitis when individuals are exposed via dermal and inhalation routes [32] or through drinking water [33]. To control trihalomethanes and heavy metals in drinking water, international and local organizations, such as the World Health Organization and the United States Environmental Protection Agency, set safe limits for the pollutants, while the International Agency for Research on Cancer determined a cancer risk (Table 1) $[25,34,35]$.

The principle aim of this study was to investigate the potential of the water vending machine for $\mathrm{CHCl}_{3}$, $\mathrm{CHBr}_{3}, \mathrm{CHCl}_{2} \mathrm{Br}, \mathrm{Pb}^{2+}$, and $\mathrm{Cr}^{6+}$ removal during the high and low water seasons. We hypothesized that the water vending machine may reduce the pollutant concentrations in both the high and low water seasons.

\section{Materials and Methods}

\section{Study Area}

Petropavlovsk $\left(54^{\circ} 53^{\prime} \mathrm{N} \quad 69^{\circ} 10^{\prime} \mathrm{E}\right)$ is a city in the North Kazakhstan Region. It has an urban area of $224.9 \mathrm{~km}^{2}$ and a population of 219.2 thousand people. The total household water demand is approximately 
Table 1. THMs and HMs guideline values $(\mu \mathrm{g} / \mathrm{L})$ and cancer risk classification $[12,20,21]$.

\begin{tabular}{|c|c|c|c|}
\hline Agent & WHO & EPA & IARC \\
\hline $\mathrm{CHCl}_{3}$ & 300 & 80 & $2 \mathrm{~B}^{\mathrm{a}}$ \\
\hline $\mathrm{CHBr}_{3}$ & 100 & 80 & $3^{\mathrm{b}}$ \\
\hline $\mathrm{CHCl}_{2} \mathrm{Br}$ & 60 & 80 & $2 \mathrm{~B}$ \\
\hline $\mathrm{Pb}^{2+}$ & 10 & 15 & $2 \mathrm{~A}^{\mathrm{c}}$ \\
\hline $\mathrm{Cr}^{6+}$ & 50 & 100 & $1^{\mathrm{d}}$ \\
\hline
\end{tabular}

Note: $2 \mathrm{~B}^{\mathrm{a}}=$ possibly carcinogenic to humans;

$3^{\mathrm{b}}=$ not classifiable as to its carcinogenicity to humans;

$2 \mathrm{~A}^{\mathrm{c}}=$ probably carcinogenic to humans; $1^{\mathrm{d}}=$ carcinogenic to humans.

$31,400 \mathrm{~m}^{3} / \mathrm{d}$, which is supplied only by the Petropavlovsk drinking water supply enterprise. The daily water production of the enterprise is $480,000 \mathrm{~m}^{3} /$ day for household and industrial needs. Water sampling was carried out from the enterprise's supply network.

\section{DWSE Purification Process}

Basically, the purification process at the company consists of several stages: mechanical cleaning with rotating nets, coagulation, flocculation, sedimentation, preliminary chlorination, zeolite filtration, and final chlorination.

Mechanical treatment is a rough cleaning with rotating nets with cells of $5 \times 5 \mathrm{~mm}$, it is performed when taking raw water from the river. Coagulation is performed with aluminum sulfate $\left(\mathrm{Al}_{2}\left(\mathrm{SO}_{4}\right)_{3}\right)$ in order to promote adhesion of solids, then flocculation is implemented with polyacrylamide (PAM) to make flocs to settle the substances down in sedimentation stage. Preliminary chlorination is carried out after the rough cleaning. The final chlorination is performed at the end of the water purification process. Pretreatment of the disinfectant is performed as chlorine is supplied in metallic containers and may have undesirable pollutants. The pretreatment is implemented in an intermediate tank (sump) where the state of the chlorine varies from liquid to gaseous, and the undesirable pollutants are removed. Next, chlorine goes from the intermediate tank to a chlorinator LONII 100. Finally, the chlorinated solution is introduced into raw water. The concentration of chlorine in the finished water is fixed at 0.3-0.5 $\mathrm{mg} / \mathrm{L}$. Zeolite filtration occurs between the chlorination phases. Zeolite filters have an area of $30.2 \mathrm{~m}^{2}$ and a thickness of 2.4-2.8 m. Zeolite fraction is between 0.8 and $1.2 \mathrm{~mm}$. In total, raw water flows through 6-7 zeolite filters, depending on the pump station. The flushing of the filter is provided by waterair. The filter shall be stopped for flushing if the quality of the water deteriorates at least once a day.

\section{WVM Purification Process}

The beginning stage of the purification process is a $5-\mu \mathrm{g}$ polypropylene sediment filtration cartridge $\left(\mathrm{SF}_{5}\right)$. The next step is a granular activated carbon cartridge (GAC1), and the third stage is a $1 \mu \mathrm{g}$ polypropylene sediment filtration cartridge $\left(\mathrm{SF}_{1}\right)$. Following that, the reverse osmosis membrane stage with a membrane pore size of $0.001 \mu \mathrm{g}$ begins, and it proceeds under pressure in the range of 0.4-0.6 MPa. Next, the post-granular activated carbon cartridge (GAC2) and calcite-mineralization cartridge (CM) are used, followed by an ultraviolet lamp with the wavelength of $260 \mathrm{~nm}\left(\mathrm{UV}_{260}\right)$. The last stage of the vending machine purification is ozonation. It is performed via 10 seconds of $\mathrm{O}_{3}$ exposure with a dosage of $0.5 \mathrm{mg} / \mathrm{L}$. It should be noted that the ozone treatment is performed on an empty vessel which is then filled with water. The scheme of vending machine and its purification process are presented in Fig. 1 and Fig. 2.

Normally, SFs and GAC1 cartridges are replaced approximately every 2 months or less. GAC2 and CM cartridges are replaced about every 6 months, while the membrane serves for 1 year. The UV lamp is replaced after 1.5 years of exploitation. The ozonator serves around 6 years until the next replacement. The machine water flow speed is around $7.5 \mathrm{~s} / \mathrm{L}$, and the production capacity of drinking water is $2-4.2 \mathrm{~L} / \mathrm{min}$. The volume of the machine tank ranges from 200 to $500 \mathrm{~L}$.

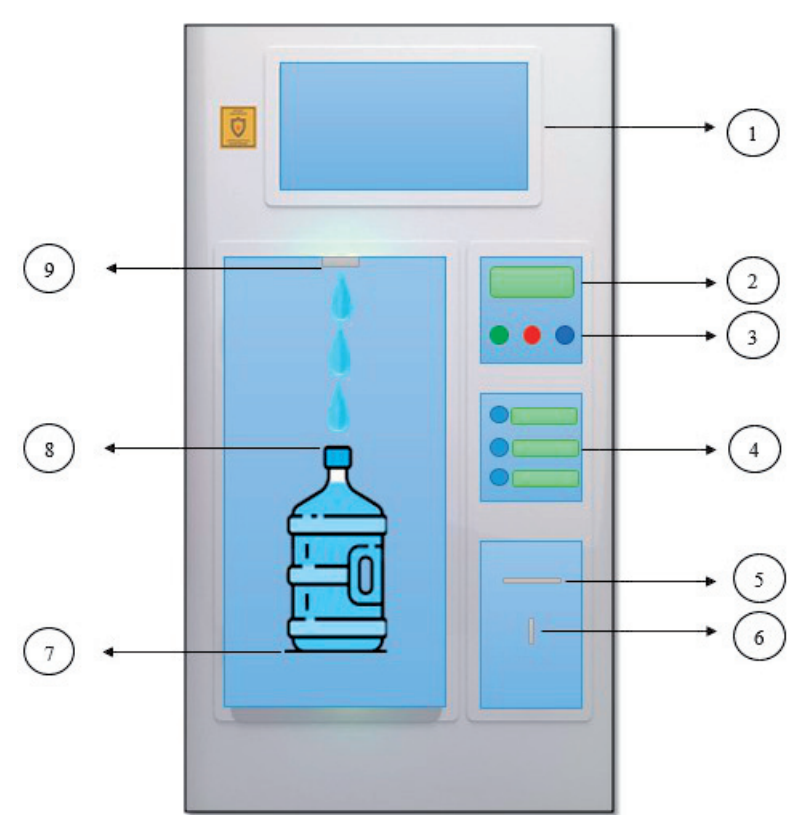

Fig. 1. The water vending machine scheme.

Legend: 1 - company labeling; 2 - operational screen; 3 - functional buttons (green - start, red - stop, blue - ozone); 4 - vessel volume options; 5 - bill acceptor; 6 - coin acceptor; 7 - vessel stand; 8 - vessel; 9 - tap. 


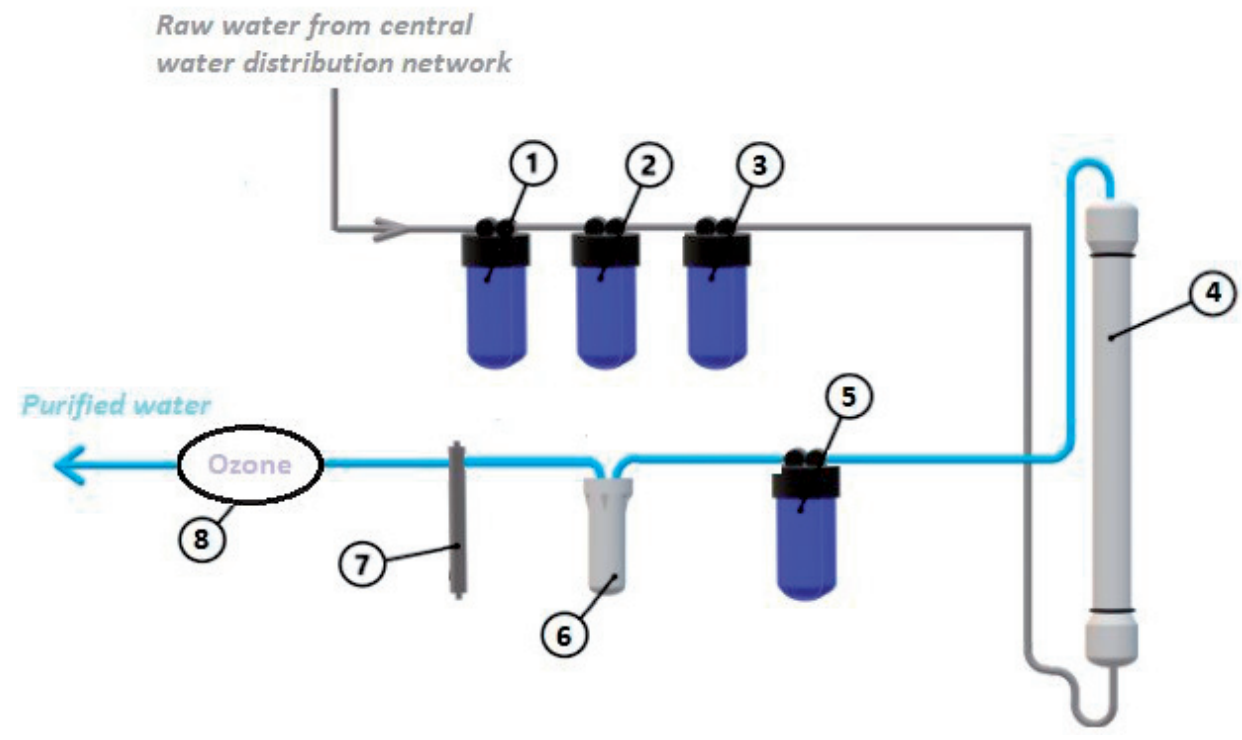

Fig. 2. The water vending machine purification process.

Legend: $1-5$ - $\mu$ g polypropylene sediment filtration cartridge; 2 - granular activated carbon cartridge; 3 - $1-\mu \mathrm{g}$ polypropylene sediment filtration cartridge; 4 - reverse osmosis membrane stage; 5 - granular activated carbon cartridge; 6 - calcite-mineralization cartridge; 7 - ultraviolet lamp; 8 - ozonation.

\section{Water Sampling}

Two types of drinking water were defined: classically purified drinking water (CPDW), which was treated only by the supply enterprise, and advanced purified drinking water (APDW), when first, samples were purified by the supply enterprise, and then additionally treated by the vending machine. Water samples of CPDW and APDW were collected from the water distribution supply network in the mornings in May (high water) and September (low water) of 2020. The samples were taken around 5, 10, 15, 20, and 25 kilometers away from the plant of the enterprise. In total, 20 samples were collected from 5 sites in the study area.

$\mathrm{CHCl}_{3}, \mathrm{CHBr}_{3}$, and $\mathrm{CHBrCl}_{2}$ samples were put in dark glass vials of $1 \mathrm{~L}$, being pre-sterilized with distilled water. Generally, THMs water sampling was implemented based on several previous studies [36-38] with minor changes, while HMs sampling instruction was obtained in "Sanitary and Epidemiological Requirements, 2015" released by the Ministry of National Economy [39]. According to the requirements, $\mathrm{Pb}^{2+}$ and $\mathrm{Cr}^{6+}$ samples were taken in polymer vials of $2 \mathrm{~L}$, pre-washed with nitric acid, distilled water, and by analyzed water itself. When the samples were being taken, faucets were turned on and allowed to run for about $5 \mathrm{~min}$ to obtain water from the water distribution system; bottles were filled completely without visible gas bubbles. The water samples were then placed in a black case and stored at $4^{\circ} \mathrm{C}$ until they were transported to the National Centre of Expertise, Kazakhstan, Petropavlovsk. The transportation of the samples lasted not more than 4 hours.

\section{Laboratory Analysis}

The laboratory employees, analyzing the pollutants, used the following equipment: THMs were explored using a gas chromatograph-mass spectrometer (GCMS 7890B, Agilent Technologies, USA) equipped with a DB-624 capillary column $(60 \mathrm{~m} \times 0.32 \mathrm{~mm} \times 1.80 \mathrm{~mm})$ and an electron capture detector (ECD) after liquidliquid extraction by methyl tert-butyl ether (MTBE). The limit of detection (LOD) was determined to be $0.1 \mu \mathrm{g} / \mathrm{L}$ for each trihalomethane species, while $\mathrm{Pb}^{2+}$ and $\mathrm{Cr}^{6+}$ were detected using an atomic absorption spectrometer (SpectrAA 55, Agilent Technologies, USA). The heavy metal concentrations were studied with typical performance settings. $\mathrm{Pb}^{2+}$ was determined in wavelength of $283.3 \mathrm{~nm}$ and detection limit of $0.2 \mu \mathrm{g} / \mathrm{L}$ by UltraAA lamp, while $\mathrm{Cr}^{6+}$ - in wavelength of $357.9 \mathrm{~nm}$ and detection limit of $0.075 \mu \mathrm{g} / \mathrm{L}$. In order to obtain higher accuracy, measurements of the parameters were performed in five replications.

\section{Statistical Analysis}

To determine whether the findings were normally distributed, the parameter results were tested for the Gaussian distribution by using the non-parametric Shapiro-Wilk test. The mean concentrations of the pollutants as well as the standard error of the mean concentrations were explored by applying descriptive statistics. The statistically significant differences between the mean values of the pollutants of the two water types were examined by applying the Mann-Whitney $U$ test. The statistical hypotheses were accepted if $\mathrm{p}$-value $(p)$ was $<0.05$. The data were 
Table 2. THM and HM concentrations $(\mu \mathrm{g} / \mathrm{L})$ in May 2020.

\begin{tabular}{|c|c|c|c|c|c|c|c|c|c|c|}
\hline \multirow{2}{*}{ Agent } & \multicolumn{4}{|c|}{ CPDW } & \multicolumn{4}{c|}{ APDW } \\
\cline { 2 - 13 } & Mean & SE & Max & Min & $95 \% \mathrm{CI}^{\mathrm{b}}$ & Mean & SE $^{\mathrm{a}}$ & Max & Min & $95 \% \mathrm{CI}$ \\
\hline $\mathrm{CHCl}_{3}$ & 28.8 & 1.3 & 32 & 24 & $26.3-31.3$ & 13.1 & 1.4 & 17 & 9.5 & $10.4-15.8$ \\
\hline $\mathrm{CHBr}_{3}$ & 27.5 & 16.5 & 44 & 11 & $0-56.8$ & BDL $^{\mathrm{c}}$ & BDL & BDL & BDL & BDL \\
\hline $\mathrm{CHCl}_{2} \mathrm{Br}$ & 18.3 & 2.9 & 28 & 11 & $12.6-24.0$ & 23.1 & 2.5 & 28 & BDL & $18.2-28.0$ \\
\hline $\mathrm{Cr}^{6+}$ & BDL & BDL & BDL & BDL & BDL & BDL & BDL & BDL & BDL & BDL \\
\hline $\mathrm{Pb}^{2+}$ & 0.7 & 0.1 & 0.9 & 0.3 & $0.5-0.9$ & 0.1 & 0.01 & 0.09 & BDL & $0.08-0.12$ \\
\hline
\end{tabular}

Note: ${ }^{\mathrm{a}} \mathrm{SE}=$ standard error; ${ }^{\mathrm{b}} \mathrm{CI}=$ confidence interval; ${ }^{\mathrm{c}} \mathrm{BDL}=$ below the detection limit.

analyzed using the Statistical Package for the Social Sciences 26 software for Windows (SPSS Inc., Chicago, IL, USA).

\section{Results and Discussion}

\section{Results during the High Water Season}

The findings of the present study for the classically and advanced purified drinking water parameters during the high water season are shown in Table 2. The mean concentrations of $\mathrm{CHCl}_{3}, \mathrm{CHBr}_{3}, \mathrm{CHCl}_{2} \mathrm{Br}, \mathrm{Cr}^{6+}$, and $\mathrm{Pb}^{2+}$ in CPDW were as follows: $28.8 \mu \mathrm{g} / \mathrm{L}, 27.5 \mu \mathrm{g} / \mathrm{L}$, $18.3 \mu \mathrm{g} / \mathrm{L}$, below the detection limit (BDL), and $0.7 \mu \mathrm{g} / \mathrm{L}$, respectively. Meanwhile, the concentrations of $\mathrm{CHCl}_{3}, \mathrm{CHBr}_{3}, \mathrm{CHCl}_{2} \mathrm{Br}, \mathrm{Cr}^{6+}$, and $\mathrm{Pb}^{2+}$ in APDW were $13.1 \mu \mathrm{g} / \mathrm{L}, \mathrm{BDL}, 23.1 \mu \mathrm{g} / \mathrm{L}, \mathrm{BDL}$, and $0.1 \mu \mathrm{g} / \mathrm{L}$, respectively. The total concentrations of the three trihalomethanes during the high water season in CPDW and APDW were $74.5 \mu \mathrm{g} / \mathrm{L}$ and $36.3 \mu \mathrm{g} / \mathrm{L}$, respectively. The highest share of the total trihalomethane concentrations in CPDW was taken by $\mathrm{CHCl}_{3}$ (38.6\%), while in APDW - by $\mathrm{CHCl}_{2} \mathrm{Br}$ (63.8\%). During the high water season, the concentrations of organochlorine compounds and dissolved ions in the decreasing order were as follows: $\mathrm{CHCl}_{3}>\mathrm{CHBr}_{3} \mathrm{CHCl}_{2}>\mathrm{Pb}^{2+}>\mathrm{Cr}^{6+}$, while in APDW, they were $\mathrm{CHCl}_{2} \mathrm{Br}>\mathrm{CHCl}_{3}>\mathrm{Pb}^{2+}>\mathrm{CHBr}_{3}>\mathrm{Cr}^{6+}$. Higher concentrations of chloroform, bromoform, and bromodichloromethane during the high water season were detected in the classically purified drinking water of Ardabil city in Iran [40], while lower concentrations of the contaminants were found in the drinking water of Cordoba city, Spain [38]. In addition, the concentration of chloroform and bromodichloromethane were lower in studies by Lee and colleagues [41]. A similar concentration of lead in the classically purified drinking water was found in West Lafayette, Indiana, USA [42]. Meanwhile, the concentrations of lead in this water type were essentially higher in Sulaimaniyah Province in Iraq during the high water season [43]. Greater concentrations of chromium ions were found in two tap water treatment plants in Shenzhen in May [44]. In addition, the concentrations of chromium were higher in Oinofita municipality of Greece [45]. Another study showed similar results concerning chromium concentrations in drinking water in two areas in Central Greece [46]. The studies on the potential of drinking water vending machines to remove organochlorine compounds (particularly, trihalomethanes) are scarce. Finding such studies for specific seasons is even more complicated. Therefore, in this study, we could not compare our results on the concentrations in trihalomethane in advanced purified drinking water with those of other studies since we did not find any similar studies. Meanwhile, we could compare the concentrations of chromium and lead in advanced purified water to those found in other studies. The comparison showed that higher concentrations of the heavy metal ions were detected in Parit Raja city in Malaysia during the high water season [18].

\section{Results during the Low Water Season}

The results of this study on the parameters of classically and advanced treated water during the low water season are described in Table 3. The research findings showed that the mean concentration of $\mathrm{CHCl}_{3}, \mathrm{CHBr}_{3}, \mathrm{CHCl}_{2} \mathrm{Br}, \mathrm{Cr}^{6+}$, and $\mathrm{Pb}^{2+}$ in $\mathrm{CPDW}$ were $13.5 \mu \mathrm{g} / \mathrm{L}, 45 \mu \mathrm{g} / \mathrm{L}, 1.5 \mu \mathrm{g} / \mathrm{L}, 4.1 \mu \mathrm{g} / \mathrm{L}$, and $0.3 \mu \mathrm{g} / \mathrm{L}$, respectively. Meanwhile, the concentration of $\mathrm{CHCl}_{3}$ and $\mathrm{Pb}^{2+}$ in APDW were $4.4 \mu \mathrm{g} / \mathrm{L}$ and $0.04 \mu \mathrm{g} / \mathrm{L}$, respectively. The concentrations of the remaining contaminants in APDW were below the detection limit. The overall concentrations of trihalomethanes in CPDW and APDW were $60 \mu \mathrm{g} / \mathrm{L}$ and $4.4 \mu \mathrm{g} / \mathrm{L}$, respectively. $\mathrm{CHBr}_{3}(75 \%)$ and $\mathrm{CHCl}_{3}(100 \%)$ made the highest proportion of the total trihalomethanes in the classically and advanced purified water, respectively. The concentrations of the pollutants in CPDW in decreasing order were $\mathrm{CHBr}_{3}>\mathrm{CHCl}_{3}>\mathrm{Cr}^{6+}>\mathrm{CHCl}_{2} \mathrm{Br}>\mathrm{Pb}^{2+}$. Meanwhile, the respective concentrations in APDW were the following: $\mathrm{CHCl}_{3}>\mathrm{Pb}^{2+}>\mathrm{CHBr}_{3}>\mathrm{CHCl}_{2} \mathrm{Br}>\mathrm{Cr}^{6+}$. The results of studies by Sadeghi and colleagues and by Lee and 
Table 3. THM and HM concentrations $(\mu \mathrm{g} / \mathrm{L})$ in September 2020.

\begin{tabular}{|c|c|c|c|c|c|c|c|c|c|c|}
\hline \multirow{2}{*}{ Agent } & \multicolumn{4}{|c|}{ CPDW } & \multicolumn{4}{c|}{ APDW } \\
\cline { 2 - 12 } & Mean & SE & Max & Min & $95 \% \mathrm{CI}^{\mathrm{b}}$ & Mean & SE & Max & Min & $95 \%$ CI \\
\hline $\mathrm{CHCl}_{3}$ & 13.5 & 1.8 & 20 & 10 & $9.9-17.0$ & 4.4 & 1.3 & 9 & 2 & $1.9-7.0$ \\
\hline $\mathrm{CHBr}_{3}$ & 45 & 11.6 & 90 & 30 & $22.3-67.7$ & BDL $^{\mathrm{c}}$ & BDL & BDL & BDL & BDL \\
\hline $\mathrm{CHCl}_{2} \mathrm{Br}$ & 1.5 & 0.9 & 2.4 & 0.6 & $0-3.3$ & BDL & BDL & BDL & BDL & BDL \\
\hline $\mathrm{Cr}^{6+}$ & 4.1 & 2.7 & 9.4 & 0.4 & $0-9.4$ & BDL & BDL & BDL & BDL & BDL \\
\hline $\mathrm{Pb}^{2+}$ & 0.3 & 0.04 & 0.4 & 0.2 & $0.2-0.4$ & 0.04 & 0.01 & 0.06 & 0.01 & $0.02-0.06$ \\
\hline
\end{tabular}

Note: ${ }^{\mathrm{a}} \mathrm{SE}=$ standard error; ${ }^{\mathrm{b}} \mathrm{CI}=$ confidence interval; ${ }^{\mathrm{c}} \mathrm{BDL}=$ below the detection limit.

colleagues [36, 37] showed higher concentrations of chloroform and bromodichloromethane in the classically purified drinking water during the low water season, yet the concentrations of bromoform found in a study by Sadeghi et al,, were lower compared to our findings. Similar results for chloroform and bromodichloromethane concentrations in drinking water for the season were found in a study by Serrano et al. [38]. Studies conducted by researchers from Indiana, USA, yielded similar results concerning lead concentration in the classically purified drinking water during the low water season [42] while Iraq scientists from Sulaimaniyah Province found higher concentrations of lead in the drinking water during the season [43] The results of our study showed higher concentrations of chromium in the classically purified drinking water compared to those found by $\mathrm{Lu}$ and colleagues during the season [44]. However, a study conducted in Oinofita municipality in Greece claimed a higher concentration of chromium ions in the classically purified drinking water during the low water season [45] than the results in the current study showed. As mentioned in the section on the results during the high water season, finding studies on the removal of organochlorine compounds by vending machines is challenging. As a result, our findings for the three advanced filtered trihalomethanes during the low water season were not compared to the results of other studies. Higher concentrations of chromium in the vending machine water during the low water season were discovered in a comparative study on heavy metals in water types from Egypt and Saudi Arabia, while the concentrations of lead were lower [19].

\section{The Removal Potential of the Water Vending Machine}

The removal potential of the water vending machine to the studied parameters in the high and low water seasons is shown in Fig. 2. The decrease in chloroform concentrations during the high water season was $15.6 \mu \mathrm{g} / \mathrm{L}$ (around 2.2 times, or by $54.3 \%$ ), while it was $9.1 \mu \mathrm{g} / \mathrm{L}$ (around 3.1 times, or by $67.4 \%$ ) during the low water season. Statistically significant differences were found in chloroform concentrations between the classically purified and the advanced purified water at $p=0.009$ during both water seasons.

Unexpectedly, bromodichloromethane concentrations were increased by $4.9 \mu \mathrm{g} / \mathrm{L}$, or by $26.7 \%$, during the high water season. There were no statistically significant differences in bromodichloromethane concentrations between the classically purified and the advanced purified drinking water $(p=0.675)$. The concentrations of bromodichloromethane decreased from $1.5 \mu \mathrm{g} / \mathrm{L}$ to below the detection limit, or by $100 \%$, during the low water season. There were no statistically significant differences in bromodichloromethane concentrations between the classically purified and the advanced purified drinking water $(p=0.136)$.

The concentrations of bromoform decreased from $27.5 \mu \mathrm{g} / \mathrm{L}$ during the high water season and from $45 \mu \mathrm{g} / \mathrm{L}$ during the low water season to below the detection limit, or by $100 \%$. The difference of bromoform concentrations between the classically purified and advanced purified drinking water during the high water seasons was not statistically significant $(p=0.136)$, while it was statistically significant during the low water season $(p=0.005)$. The total trihalomethanes were removed by $51.4 \%$ and $92.7 \%$ in the high and low water seasons, respectively. The differences of the total trihalomethanes concentrations between the classically purified and advanced purified drinking water were not statistically significant during the high water season $(p=0.081)$, however, they were during the low water season $(p=0.020)$. We did not find any scientific data on the removal efficiency of the drinking water vending machine for trihalomethanes. However, the results of this study concerning organochlorine compounds were compared to others considering a household reverse osmosis and granular activated carbon (GAC) filtering systems which was previously studied for the removal of the pollutants [47, 48]. Thus, a similar removal efficiency by reverse osmosis filtering system for chloroform was found in a study conducted in Barcelona for both seasons, although the results of this study showed a lower bromoform and bromodichloromethane retention coefficients [47] if compared to the vending 
machine removal potential during the low water season. A higher efficiency of chloroform removal by the domestic reverse osmosis system was found in studies by Mazloomi et al. [48]. A similar granular activated carbon removal efficiency for total trihalomethanes were shown by studies of Haghighat and Mohammad-Khah, Rasheed and collegues, and Lou et al. [49, 50, 51] if compared to the water vending machine removal potential during the low water season, however, all the three studies' results are significantly higher than those in the current study during the high water season. Other studies showed substantially lower removal potential of granular activated carbon to total trihalomethanes compared to the both season results [52, 53, 54]. Kim and Kang found that after three months of GAC operation, the removal potential was quickly depleted, resulting in only a $10 \%$ removal of THMs. Another study confirmed the limited elimination of trihalomethanes (7-24\%), with chloroform having the lowest removal potential observed [54]. Similarly, Tang and Xie revealed no significant removal potential of THMs (9\%) by GAC for the treatment of swimming pool waters [53].

The water vending machine decreased lead concentrations by $0.6 \mu \mathrm{g} / \mathrm{L}$ (by around 11 times, or by $88.9 \%$ ) and by $0.23 \mu \mathrm{g} / \mathrm{L}$ (by 7 times, or by $84.5 \%$ ) during the high and low water seasons, respectively. The differences in $\mathrm{Pb}^{2+}$ concentrations between the classically and advanced purified water were statistically significant at alpha $=0.009$ during the high water season and at alpha $=0.008$ during the low water season. The concentration of $\mathrm{Cr}^{6+}$ was decreased from $2.45 \mu \mathrm{g} / \mathrm{L}$ to below the detection limit (by 100\%) during the low water season. There was no statistically significant difference of chromium concentrations between the classically and advanced purified water $(p=0.081)$. The removal efficiency of heavy metals by the advanced purification method was significantly lower in studies conducted in Malaysia [55], while similar heavy metal retention coefficients could be derived from studies carried out in Egypt [19].
We investigated the potential of the drinking water vending machine for the removal of chloroform, bromoform, bromodichloromethane, lead, and hexavalent chromium during the high and low water seasons in Petropavlovsk city, Kazakhstan. For this purpose, two types of drinking water were identified - classically purified drinking water, which is supplied by the enterprise through water pipelines, and advanced purified drinking water, which was additionally purified by the vending machine after the enterprise purification. The results of the two purification methods were then compared between each other during the high and low water seasons. The study showed that the use of a drinking water vending machine as an additional treatment device for drinking water supplied through water distribution networks plays an important role in reducing the concentration of potentially hazardous non-regulated and regulated chemicals such as chloroform, bromoform, lead, and hexavalent chromium during the high and low water seasons. It should be noted that the exception was the concentration of bromodichloromethane, which increased slightly during the high water season. The small increase in the concentration of bromodichloromethane could be due to the activity of the ultraviolet lamp [56], since ultraviolet disinfection, one of the stages of the process of purification of the vending machine, certainly takes place during the high water season when there is a high probability of bacteriological contamination in both raw and drinking water, although it may not work during the low water season for energy savings as there is a negligible risk of bacteriological contamination. Thus, residents of Petropavlovsk who consume drinking water purified by the water vending machine are less exposed to chloroform, bromoform, lead, and hexavalent chromium and are relatively similarly exposed to bromodichloromethane as those who use classically purified water. It should be emphasized that lower concentrations of pollutants reduce the risk of cancer and chronic diseases [28-33]. It should also be noted that no studies on the potential for the removal of organochlorine compounds by the drinking water

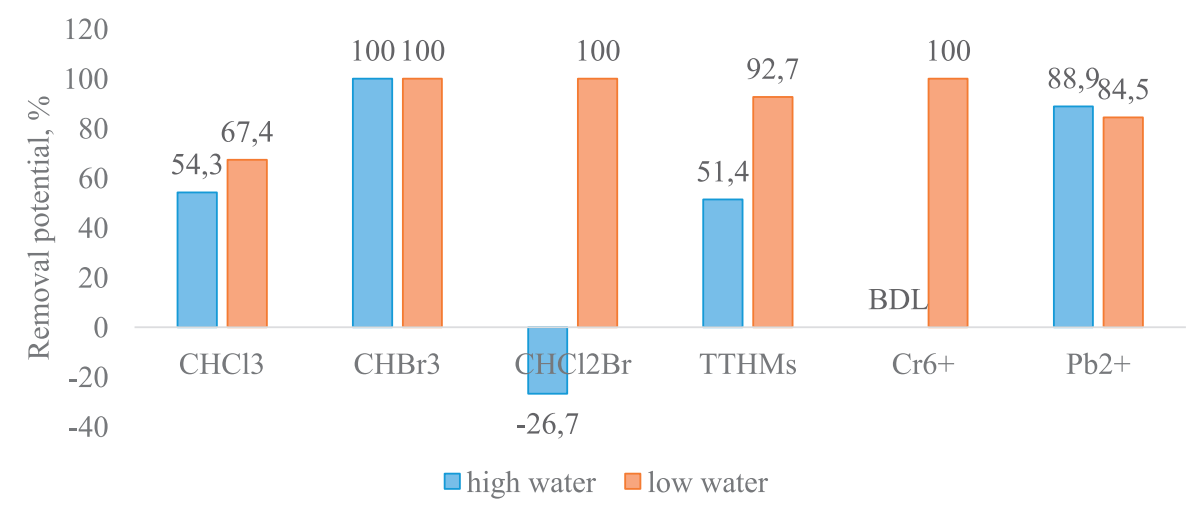

Fig. 3. The removal potential of the water vending machine for $\mathrm{CHCl}_{3}, \mathrm{CHBr}_{3}, \mathrm{CHCl}_{2} \mathrm{Br}, \mathrm{TTHMs}, \mathrm{Cr}^{6+}$, and $\mathrm{Pb}^{2+}$ in the high and low water seasons, $\%$. 
vending machine were found in scientific literature, although the efficacy of the removal of lead and hexavalent chromium by the machine was considered in several studies [19, 55], yet these investigations did not take into account seasonal properties. Due to the absence of studies on the trihalomethane removal potential by water vending machines, we guessed that the current trihalomethane removal potential by the water vending machine, which consists of eight different treatment stages, including a reverse osmosis membrane and granular activated carbon, could be fairly compared with other, similar installations that consisted only of reverse osmosis and/or a granular activated carbon filters [50-52, 57]. This study thus fills the gap and will allow for future scientific research on the effectiveness of the removal of trihalomethanes and heavy metals by the water vending machine, carrying out a comparative analysis based on the seasons. However, considering the potential of the vending machine to remove trihalomethanes, we should say that we did not study the fourth species of trihalomethanes, bromodichloromethane $\left(\mathrm{CHBr}_{2} \mathrm{Cl}\right)$. Future studies would therefore be needed to shed some light on the potential of the water vending machine to remove this pollutant. In addition, the potential of the water vending machine to remove pollutants during the inter-season period could be an interesting topic for future investigations.

\section{Conclusions}

The present study suggests the removal potential of the drinking water vending machine for the most of trihalomethanes and all heavy metals studied during the high and low water seasons.

Using the drinking water vending machine, the level of chloroform and total trihalomethanes can be reduced by $54.3 \%$ and $51.4 \%$, respectively, while bromoform and lead can be reduced by $100 \%$ and $88.9 \%$, respectively, during the low water season. However, the only exception is that the water vending machine might not be effective in removing of bromodichloromethane during the low water season.

The drinking water vending machine may moderately reduce the level of chloroform by $67.4 \%$ and it may highly reduce the level of lead by $84.5 \%$, total trihalomethanes by $92.7 \%$, bromodichloromethane by $100 \%$, bromoform by $100 \%$, and chromium by $100 \%$ in the high water season.

\section{Acknowledgment}

The authors acknowledge "Kyzyl-Zhar Su" Limited Liability Partnership and "Alive Water" Limited Liability Company for providing information on the water purification processes.

\section{Conflict of Interest}

The authors declare no conflict of interest.

\section{References}

1. Basic Requirements for Prospective Water Vending Machine Operators. Available online: https://ldh.la.gov/ assets/oph/Center-EH/sanitarian/fooddrug/Guidelinesfor ProspectiveWaterVendingMachineOperators3-5-10.pdf (accessed 2409 2021).

2. PRICE J.H., MURNAN J., MOORE B. Soft drink vending machines in schools: a clear and present danger. Am J Health Edu 37, 306, 2006.

3. KARALGIKAR R., KUMAR H.P. Smart Water Vending Machine. International Journal of Research in Engineering, Science and Management. 2 (9), 225, 2019.

4. SCHILLINGER J., DU VALL KNORR S. Drinking-water quality and issues associated with water vending machines in the city of Los Angeles. J Environ Health, 66 (6), 25, 2004.

5. MOOSA M.E., KHAN M.A., ALALAMI U., HUSSAIN A. Microbiological quality of drinking water from water dispenser machines. International Journal of Environmental Science and Development, 6 (9), 710, 2015.

6. MCSWANE D.Z., OLECKNO W.A., ELIS L.M. Drinking water quality concerns and water vending machines. Journal of Environmental Health, 56 (10), 7, 1994.

7. MOOMMALA N., PHANUCHARAS D., KRICHANCHAI S., KAPOL N. Supervision of automatic drinking water vending machine. Thai Bull Pharm Sci., 16 (1), 75, 2021.

8. SAENGLAI L., JAMSRI P., PUKSUN K., TEERASMIT K., KANNIKA J. Risk assessment of drinking water from vending machines in the central area and support of establishment of the quality standard. Bull Dept Med Sci., 57 (1), 22, 2015.

9. SOMBATWATHANAWET M., RUENGORN C. Situation on drinking water quality from water vending machines and maintenance system in Chiangmuan district, Phayao province. Thai J Pharm Prac., 12 (2), 388, 2020.

10. VETTAYANONT K. Impact of the policy on Pracharath drinking water in Kanchanaburi province. Thai J Pharm Prac., 10 (1), 219, 2018.

11. CARRASCO-TURIGAS G., VILLANUEVA C.M., GOÑI F., RANTAKOKKO P., NIEUWENHUIJSEN M.J. The effect of different boiling and filtering devices on the concentration of disinfection by-products in tap water. Journal of Environmental and Public Health, 2013, 959480, 2013.

12. MAZLOOMI S., NABIZADH R., NASSERI S., NADDAFI K., NAZMARA S., MAHVI A. H. Efficiency of domestic reverse osmosis in removal of trihalomethanes from drinking water. Iranian Journal of Environmental Health Science and Engineering, 6 (4), 301, 2009.

13. NELSON K.Y., MCMARTIN D.W., YOST C.K., RUNTZ K.J., ONO T. Point-of-use water disinfection using UV light-emitting diodes to reduce bacterial contamination. Environmental science and pollution research international, 20 (8), 5441, 2013.

14. SISTI M., SCHIAVANO G.F., SANTI M., BRANDI G. Ultraviolet germicidal irradiation in tap water contaminated by Aspergillus spp. Journal of preventive medicine and hygiene, 58 (4), 315, 2017. 
15. WANQING D., WENBIAO J., SONG C., XU Z., CHANGPING W., QIJUN J., HUI H., RENJIE T., SONG-FANG H., QILI, W. Ozone disinfection of chlorineresistant bacteria in drinking water, Water Research, 160, 339, 2019.

16. PRAVEENA S.M., KAMAL HUYOK N.F., BURBURE C. Public health risk assessment from drinking water from vending machines in Seri Kembangan (Malaysia). Food Control, 91 (5), 40, 2018.

17. TAN E.Y., ARIFULLAH M., SOON J.M. Identification of Escherichia coli strains from water vending machines of Kelantan, Malaysia using 16S rRNA gene sequence analysis. Exposure and Health, 8 (2), 211, 2016.

18. HASHIM N.H., YUSOP H.M. Drinking water quality of water vending machines in Parit Raja, Batu Pahat, Johor. IOP Conference Series: Materials Science and Engineering, 136 (1), 1, 2016.

19. EL-NAGGAR A.M. Heavy metal analysis in some water types from Egypt and Saudi Arabia, and future aspirations of water resources management. Journal of Bioscience and Applied Research, 2 (5), 301, 2016.

20. RICHARDSON S.D., POSTIGO. Emerging organic contaminants and human health. The Handbook of Environmental Chemistry, Springer: Heidelberg, New York, Dordrecht, London, 20, 93, 2012.

21. ROOK J.J. Formation of haloforms during chlorination of natural waters. Water Treat. Exam., 23, 234, 1974.

22. SADIQ R., RODRIGUEZ M.J. Fuzzy synthetic evaluation of disinfection byproducts - a risk-based indexing system. J. Envron. Manage. 73 (1), 1, 2004.

23. PENG C.Y., HILL A.S., FRIEDMAN M.J., VALENTINE R.L., LARSON G.S., ROMERO A.M.Y., REIBER S.H., KORSHIN G.V. Occurrence of trace inorganic contaminants in drinking water distribution systems. Journal-American Water Works Association, 104 (3), 18, 2012.

24. LIU H., YU X. Hexavalent chromium in drinking water: Chemistry, challenges and future outlook on Sn(II)-and photocatalyst-based treatment. Frontiers of environmental science \& engineering, 14 (5), 88, 2020.

25. Guidelines for Drinking-Water Quality: Fourth Edition. Available online: https://www.esdat.net/ Environmental\%20Standards/WHO/WHO_4th_Edition_ Tables.pdf (accessed 206 2021).

26. Depreciation of Water Supply Networks in Petropavlovsk is About $70 \%$, Sewer - About $60 \%$. Available online: https://izdatelstvo-sk.kz/news/otchitalis-ob-investiciyah/ (accessed 706 2021).

27. The Quality of Drinking Water Is Deteriorating Every Year in the North Kazakhstan Region. Available online: https://pkzsk.info/v-severnom-kazakhstane-s-kazhdymgodom-ukhudshaetsya-kachestvo-pitevojj-vody/ (accessed 2409 2021).

28. CHOWDHURY S. Trihalomethanes in drinking water: Effect of natural organic matter distribution. Water SA, 39 (1), 1, 2013.

29. Integrated Risk Information System. Available online: http://www.epa.gov/iris/subst/index.html (accessed 1406 2021).

30. TEMRAZ S., HAIBE Y., CHARAFEDDINE M., SAIFI O., MUKHERJI D., SHAMSEDDINE A. The unveiling of a new risk factor associated with bladder cancer in Lebanon. BMC Urology, 19 (1), 1, 2019.

31. LEVIN R. Lead in drinking water. In Economic Analyses at EPA: Assessing Regulatory Impact, Richard D. Morgenstern, ed. Taylor and Francis: New York, USA, pp. 205, 2014.
32. SHRIVASTAVA R., UPRETI R., SETH P., CHATURVEDI U. Effects of chromium on the immune system. FEMS Immunology \& Medical Microbiology, 34 (1), 1, 2002.

33. ZHITKOVICH A. Chromium in drinking water: Sources, metabolism, and cancer risks. Chemical Research in Toxicology, 24 (10), 1617, 2011.

34. 2018 Drinking Water Standards and Advisory Tables. Available online: https://www.epa.gov/sdwa/2018drinking-water-standards-and-advisory-tables (accessed on 1506 2021)

35. IARC Monographs On The Identification Of Carcinogenic Hazards To Humans. Available online: https://monographs. iarc.who.int/list-of-classificationss (accessed on 1506 2021).

36. CHARISIADIS P., ANDRA S.S., MAKRIS K.C., CHRISTOPHI C.A., SKARLATOS D., VAMVAKOUSIS V., KARGAKI S., STEPHANOU E.G. Spatial and seasonal variability of tap water disinfection by-products within distribution pipe networks. Science of the Total Environment, 506-507, 26, 2015.

37. GRAZULEVICIENE R., NIEUWENHUIJSEN M.J., VENCLOVIENE J., KOSTOPOULOU-KARADANELLI M., KRASNER S.W., DANILEVICIUTE A., BALCIUS G., KAPUSTINSKIENE V. Individual exposures to drinking water trihalomethanes, low birth weight and small for gestational age risk: A prospective Kaunas cohort study. Environmental Health: A Global Access Science Source, 10 (1), 32, 2011.

38. SERRANO M., MONTESINOS I., CARDADOR M.J., SILVA M., GALLEGO M. Seasonal evaluation of the presence of 46 disinfection by-products throughout a drinking water treatment plant. The Science of the Total Environment, 517, 246, 2015.

39. About the Approval Of Sanitary Rules: Sanitary and Epidemiological Requirements for Water Sources, Places of Water Intake for Economic and Drinking Purposes, Economic and Drinking Water Supply And Places of Cultural and Domestic Water Use and Safety of Water Objects Available online: http://adilet.zan.kz/rus/docs/ V1500010774 (accessed on 1806 2021)

40. SADEGHI H., NASSERI S., YUNESIAN M., MAHVI A. H., NABIZADEH R. Trihalomethanes in urban drinking water: measuring exposures and assessing carcinogenic risk. Journal of Environmental Health Science and Engineering volume 17 (2), 619, 2019.

41. LEE J., KIM E., ROH B., EOM S., ZOH K. Occurrence of disinfection by-products in tap water distribution systems and their associated health risk. Environmental Monitoring and Assessment, 185 (9), 7675, 2013.

42. SALEHI M., ODIMAYOMI T., RA K., LEY C., JULIEN R., NEJADHASHEMI A.P., HERNANDEZ-SUAREZ J.S., MITCHELL J., SHAH A.D., WHELTON A. An investigation of spatial and temporal drinking water quality variation in green residential plumbing. Building and Environment, 169, 106566, 2020.

43. ABDULLA S.M., JAMIL D.M., AZIZ K.H.H. Investigation in heavy metal contents of drinking water and fish from Darbandikhan and Dokan Lakes in Sulaimaniyah Province - Iraqi Kurdistan Region. IOP Conf. Ser.: Earth Environ. Sci. 612, 012023, 2020.

44. LU S.Y., ZHANG H.M., SOJINU S.O., LIU G.H., ZHANG, J.Q., NI H.G. Trace elements contamination and human health risk assessment in drinking water from Shenzhen, China. Environmental monitoring and assessment, 187 (1), 4220, 2015. 
45. LINOS, A., PETRALIAS, A., CHRISTOPHI, C. A., CHRISTOFORIDOU, E., KOUROUTOU, P., STOLTIDIS, M., VELOUDAKI, A., TZALA, E., MAKRIS, K. C., KARAGAS, M. R. Oral ingestion of hexavalent chromium through drinking water and cancer mortality in an industrial area of Greece-an ecological study. Environmental health: a global access science source, 10, 50, 2011.

46. SAZAKLI E., VILLANUEVA C.M., KOGEVINAS M., MALTEZIS K., MOUZAKI A., LEOTSINIDIS, M. (2014). Chromium in drinking water: association with biomarkers of exposure and effect. International journal of environmental research and public health, 11 (10), 10125, 2014.

47. CARRASCO-TURIGAS G., VILLANUEVA C.M., GOÑI F., RANTAKOKKO P., NIEUWENHUIJSEN, M.J. The effect of different boiling and filtering devices on the concentration of disinfection by-products in tap water. Journal of Environmental and Public Health, 2013, 959480, 2013.

48. MAZLOOMI S., NABIZADH R., NASSERI S., NADDAFI K., NAZMARA S., MAHVI A. H. Efficiency of domestic reverse osmosis in removal of trihalomethanes from drinking water. Iranian Journal of Environmental Health Science and Engineering, 6 (4), 301, 2009.

49. HAGHIGHAT M.H., MOHAMMAD-KHAH A. Removal of trihalomethanes from water using modified montmorillonite. Acta Chimica Slovenica, 67 (4), 1072, 2020.

50. RASHEED S., CAMPOS L.C., KIM J.K., ZHOU Q., HASHMI I. Optimization of total trihalomethanes' (TTHMs) and their precursors' removal by granulated activated carbon (GAC) and sand dual media by response surface methodology (RSM). Water Science and Technology: Water Supply, 16 (3), 783, 2015.

51. LOU J.-C., CHANG C.-J., CHEN W.-H., TSENG W.-B., HAN J.-Y. Removal of trihalomethanes and haloacetic acids from treated drinking water by biological activated carbon filter. Water, Air, \& Soil Pollution, 225 (2), 1851, 2014.

52. KIM J., KANG B. DBPs removal in GAC filteradsorber. Water research, 42 (1-2), 145, 2008.

53. TANG H.L., XIE Y.F. Biologically active carbon filtration for haloacetic acid removal from swimming pool water. The Science of the total environment, 541, 58, 2016.

54. WAHMAN D.G., KIRISITS M.J., KATZ L.E., SPEITEL G.E., JR. Ammonia-oxidizing bacteria in biofilters removing trihalomethanes are related to Nitrosomonas oligotropha. Applied and environmental microbiology, 77 (7), 2537, 2011

55. AHMED M.F., MOKHTAR M. BIN, ALAM L., MOHAMED C.A.R., TA G.C. Investigating the status of cadmium, chromium and lead in the drinking water supply chain to ensure drinking water quality in Malaysia. Water (Switzerland), 12 (10), 1, 2020.

56. Disinfection By-Product Formation of UV Treated Swimming Pool Water. Available online on: http://orbit. dtu.dk/files/114720483/Spiliotopoulou_Disinfection_by_ products_formation_of_UV_treated_swimming_pool_ water.pdf (accessed on 1107 2021)

57. LIU C., OLIVARES C.I., PINTO A.J., LAUDERDALE C.V., BROWN J., SELBES M., KARANFIL T. The control of disinfection byproducts and their precursors in biologically active filtration processes. Water Research, 124, 630, 2017. 